\title{
Definitive surgical treatment of osteomalacia induced by skull base tumor and determination of the half-life of serum fibroblast growth factor 23
}

Taijun Hana $^{1)}$, Shota Tanaka ${ }^{1)}$, Hirofumi Nakatomi ${ }^{1)}$, Masaaki Shojima ${ }^{1)}$, Seiji Fukumoto ${ }^{2)}$, Masako Ikemura $^{3)}$ and Nobuhito Saito ${ }^{1)}$

1) Department of Neurosurgery, Faculty of Medicine, The University of Tokyo Hospital, Tokyo, Japan

2) Department of Endocrinology, Faculty of Medicine, The University of Tokyo Hospital, Tokyo, Japan

3) Department of Pathology, Faculty of Medicine, The University of Tokyo Hospital, Tokyo, Japan

\begin{abstract}
Tumor-induced osteomalacia (TIO) is a rare paraneoplastic syndrome often associated with fibroblast growth factor 23 (FGF23)-producing tumors such as phosphaturic mesenchymal tumor, mixed connective tissue variant (PMTMCT) affecting the bone and soft tissue. We experienced a patient with progressive bone and muscle pain due to FGF23-related TIO. Venous sampling had strongly suggested the anterior skull base as a source of FGF23, which led to the discovery of a small tumor in the ethmoid sinus extending intracranially. Radical surgical resection confirmed the histological diagnosis of PMTMCT with FGF23 immunopositivity and achieved durable tumor control with complete resolution of symptoms. We serially measured serum FGF23 level before, during and after surgery and analyzed the data to determine the half-life of FGF23. Serum FGF23 level sharply declined as early as 20 minutes after en bloc tumor resection and completely normalized after surgery. The half-life of FGF23 was calculated to be approximately 18.5 minutes using single phase exponential decay model as well as semilog transformation formula. Serial measurements of serum FGF23 level can potentially declare "complete" resection of a FGF23-producing tumor and total cure of TIO; in this regard, development of its intraoperative measurement would be helpful in the management of this endocrine tumor.
\end{abstract}

Key words: Fibroblast growth factor 23, Half-Life, Phosphaturic mesenchymal tumor, Tumor induced osteomalacia, Intraoperative measurement

TUMOR-INDUCED OSTEOMALACIA (TIO) is a rare paraneoplastic syndrome first described in 1947. TIO is usually associated with hypophosphatemia due to increased urinary phosphate excretion causing muscle weakness and bone pain [1]. Recent evidence has revealed that the phenomenon is caused by the secretion of fibroblast growth factor 23 (FGF23) from kinds of tumors of bone or soft tissue $[2,3]$. Surgical removal of the FGF23-producing tumor is considered to be the most definitive treatment for TIO [4]. In this study, we analyzed perioperative serum FGF23 levels in a patient with TIO treated with complete resection of a phosphaturic mesenchymal tumor, mixed connective tissue

Submitted Apr. 26, 2017; Accepted Jun. 23, 2017 as EJ17-0177 Released online in J-STAGE as advance publication Aug. 2, 2017 Correspondence to: Shota Tanaka, M.D., Department of Neurosurgery, Faculty of Medicine, The University of Tokyo, 7-3-1 Hongo, Bunkyo-ku, Tokyo 113-8655, Japan.

E-mail: tanakas-tky@umin.ac.jp

(c) The Japan Endocrine Society variant (PMTMCT) at the anterior skull base and determined the half-life of FGF23 with a hope that its perioperative serial measurements refine the management of TIO.

\section{Materials and Methods}

\section{Patient presentation}

The patient is a 38 -year-old woman who initially presented with progressive bone and muscle pain at the age of 29 , and was found to have elevated serum FGF23 level. Subsequent development of olfactory disturbance led to the discovery of a small tumor in the ethmoid sinus, for which she underwent transnasal endoscopic surgery at the age of 36 . Histological diagnosis was PMTMCT with immunopositivity for FGF23 (Fig. 1). Since intracranial extension through the cribriform plate prevented complete resection, serum FGF23 level did not normalize nor did her 
symptoms recover fully. Rather, olfactory disturbance deteriorated further, and follow-up MRI scans showed progression of the remnant tumor with more intracranial involvement (Fig. 2). Laboratory findings included low serum phosphate level $(1.3 \mathrm{mg} /$ $\mathrm{dL}$ (reference, $2.5-4.5 \mathrm{mg} / \mathrm{dL}$ )) and high FGF23 level $(120 \mathrm{pg} / \mathrm{mL}(10-50 \mathrm{pg} / \mathrm{mL}))$. Renal function was normal (serum creatinine $0.45 \mathrm{mg} / \mathrm{dL}(0.4-0.9 \mathrm{mg} /$ $\mathrm{dL}$ ), estimated GFR $120.9 \mathrm{~mL} / \mathrm{min} / 1.73 \mathrm{~m}^{2}(90-\mathrm{mL} /$ $\left.\min / 1.73 \mathrm{~m}^{2}\right)$ ) and it remained normal throughout the subsequent course of treatment. Serum calcium level was $9.1 \mathrm{mg} / \mathrm{dL}(8.4-9.7 \mathrm{mg} / \mathrm{dL})$, iron level was $73 \mu \mathrm{g} /$ $\mathrm{dL}$ (0.4-0.9 $\mathrm{mg} / \mathrm{dL})$, and 1,25-dihydroxyvitamin D level was $20.5 \mathrm{pg} / \mathrm{mL}(20-60 \mathrm{pg} / \mathrm{mL})$. Venous sampling revealed that FGF23 level was elevated especially in several veins of the head and neck, strongly suggesting the anterior skull base tumor as a source of FGF23 (Fig. 3). Therefore, she underwent craniotomy for curative resection. The tumor as well as the invaded ethmoid bone were removed en bloc, and large defect at the skull base was repaired with a pedicle subgaleal flap. The histology of the resected tumor looked identical to that of the initial nasal tumor, and hence the diagnosis of PMTMCT (Fig. 1). At the 25-month follow-up, muscle and bone pain had completely resolved. Serum phosphate level recovered to the normal level without medications. Serum FGF23 level remained normal and MRI scan showed no recurrent tumor.

\section{Measurement of serum FGF23 level and assessment of half-life}

Intraoperatively, we sequentially collected blood samples from right medial cubital vein for the analysis of serum FGF23 level before tumor resection as well as 20 and 60 minutes after resection. Postoperatively, we continued blood sampling right after surgery and 1, 2, 4 days, 2 weeks, and 1 month after. Serum FGF23 level (a)

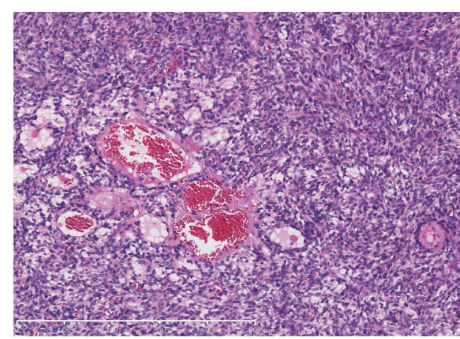

(b)

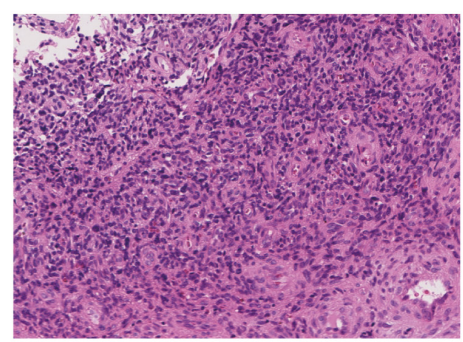

(c)

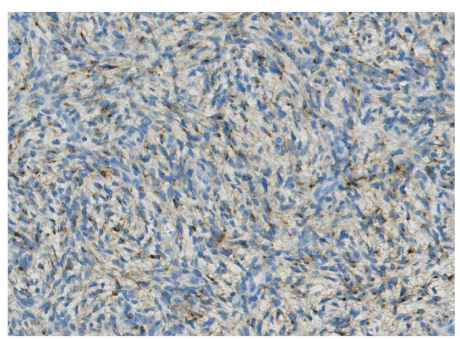

Fig. 1 Immunohistochemistry analysis

(a) Hematoxylin and eosin staining of the original intranasal tumor. Tumor cells with oval to fusiform nuclei densely proliferate. Polymorphism is not prominent. The tumor is intervened by numerous vessels of small-to-medium caliber and associated with intratumoral hemorrhage. (b) Hematoxylin and eosin staining of the recurrent intracranial tumor demonstrates that tumor cells resemble those of the original tumor. (c) Immunohistochemistry staining of the original tumor is positive for FGF23.

(a)

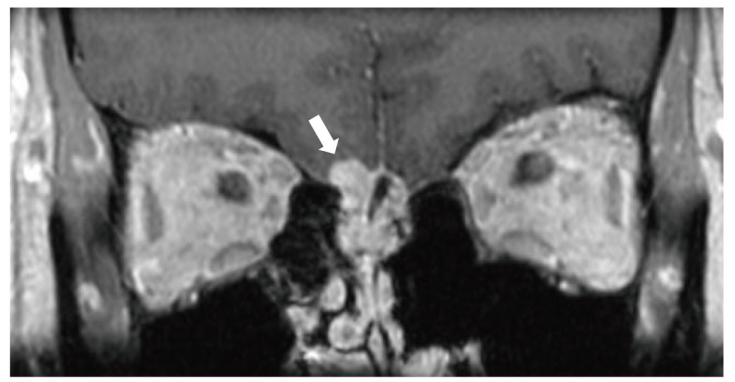

(b)

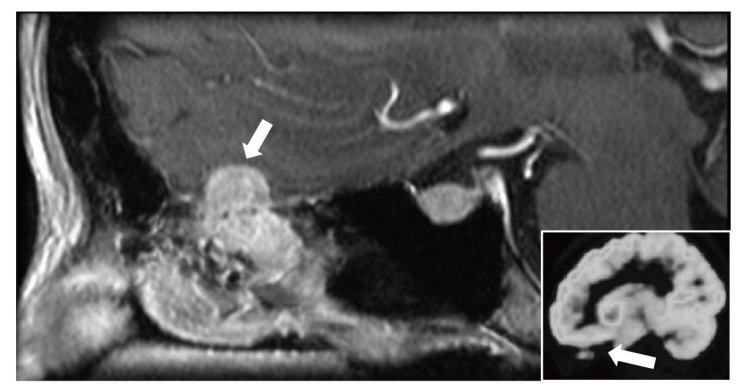

Fig. 2 Pre- and postoperative MRI scans and FDG-PET scan

Coronal (a) and sagittal (b) sections of preoperative MRI scans demonstrate an enhancing tumor at the anterior frontal skull base extruding into bilateral ethmoid sinuses (arrows). FDG-PET image is shown in a small window depicting an area of moderate uptake corresponding to the tumor. 


\begin{tabular}{|l|c|}
\hline \multicolumn{1}{|c|}{ Position } & FGF23 $(\mathrm{pg} / \mathrm{mL})$ \\
\hline A: R-IJV, pterygoid plexus & 98.1 \\
\hline B: L-IJV, common & 89.2 \\
\hline C: Superior vena cava & 86.2 \\
\hline D: R-IJV, common & 82.6 \\
\hline E: Inferior vena cava & 73.5 \\
\hline F : R-EJV, facial vein & 66.3 \\
\hline G: R-IJV, jugular bulb & 61 \\
\hline
\end{tabular}

Abbreviations: R, right; L, left; IJV, internal jugular vein; EJV, external jugular vein.

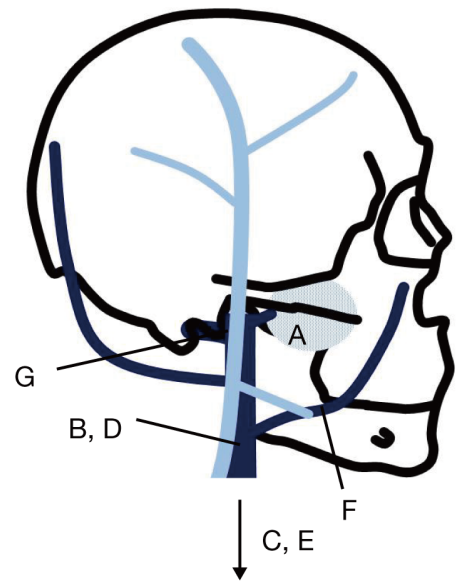

Fig. 3 Venous sampling of serum FGF23 level

Serum FGF23 levels at veins of several locations are listed in the table. The schema illustrates the locations of venous sampling. The differential serum levels suggest the origin of FGF23 secretion around the anterior skull base where the tumor is located.

was measured by intact assay (Kainos, Tokyo, Japan) [5]. The half-life of FGF23 was determined using two mathematical methods: single phase exponential decay model and semilog transformation formula. The software used was Prism 6 (GraphPad Software, San Diego CA, USA) for the former and Excel 2010 (Microsoft, Redmond WA, USA) for the latter.

\section{Results}

A sharp decline of serum FGF23 level was observed 20 minutes after tumor removal, and it normalized postoperatively (Fig. 4a). FGF23 levels at 2 weeks and 1 month after surgery were likely due to the inherent secretion of FGF23, which had been long suppressed by the FGF-producing tumor. Serum phosphate level normalized one week after surgery. A single phase exponential decay model calculated the half-life of FGF23 to be 18.4 minutes (Fig. 4b). The half-life was also calculated with semilog transformation formula. FGF23 levels at different time points were plotted to a logarithmic graph and the following exponential approximation line was obtained: $y=54.823 e^{-0.035 x}(e$ : base of natural logarithm). The half-life of FGF23 was calculated as $x$ when $y$ was $50 \%$ of the level of preoperative FGF23 level (56.7 $\mathrm{pg} / \mathrm{mL}$ ) (Fig. 4c). It was 18.9 minutes and consistent with the single phase exponential decay model. Therefore, the half-life of FGF23 was determined to be approximately 18.5 minutes.

\section{Discussion}

The cure of a paraneoplastic syndrome such as TIO is only possible when a causative tumor is totally removed from the body, usually by means of complete surgical resection. Intracranial FGF23-producing PMTMCT is extremely rare and, to the best of our knowledge, only 17 cases have been reported in the literature to date (Table 1) [6-20]. It tends to affect sterically complicated areas such as the anterior skull base. An aggressive resection putting margins to the tumor warrants "total" removal most confidently, but it requires extensive repair of the skull base. In case of recurrence, reoperation will have an even higher degree of difficulty given expected adhesion and lack of a pedicle flap available for repair. These underscore the need for establishing a reliable, and desirably real-time assessment of the extent of resection.

Serum FGF23 measurement has an important role in the follow-up management of TIO. Assessment of the extent of resection based on postoperative MRI scan is often difficult because of postoperative change, while the postoperative sequential measurements of serum FGF23 level can suggest the residual tumor if the level fails to get down to normal. In such a case, early reoperation with vigorous search for the residual would be recommended. During the follow-up, increased FGF23 level strongly suggests tumor recurrence.

There are only two reports that calculated the half-life (21.5-58 minutes) [21, 22]. Takeuchi et al. 
(a)
$(\mathrm{pg} / \mathrm{mL})$
Serum FGF23

Medial cubital vein

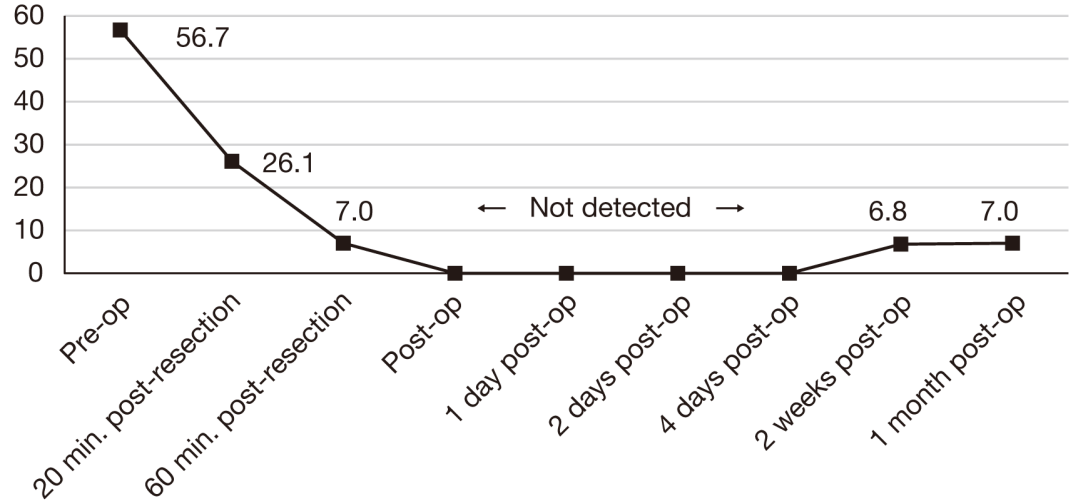

(b)

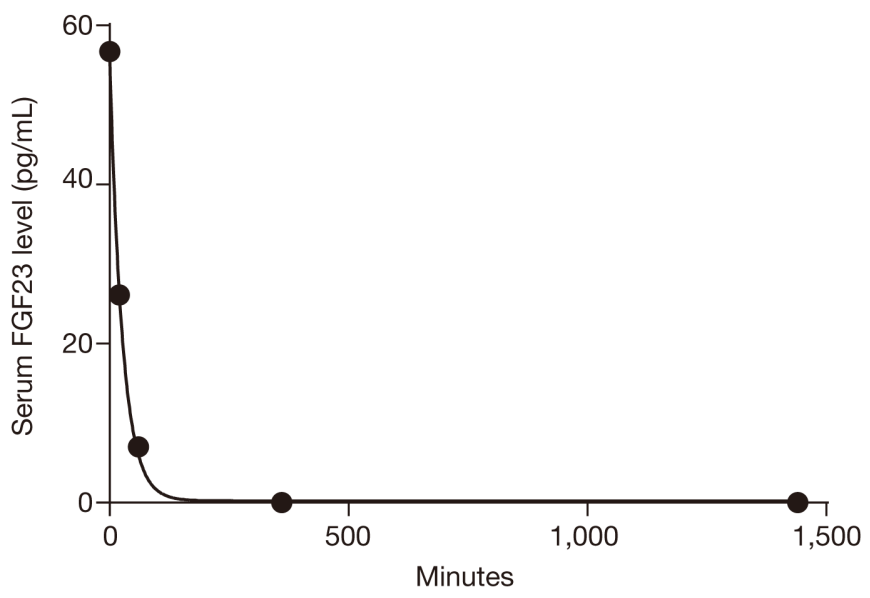

(c)

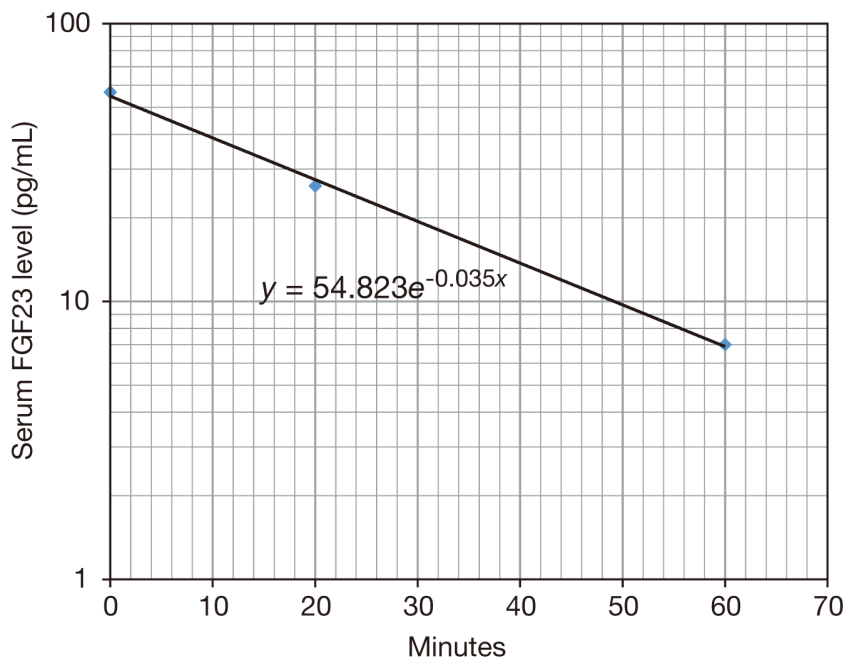

Fig. 4 Serial measurements of serum FGF23 level and calculation of its half-life

(a) Serum FGF23 level, which was elevated preoperatively, swiftly dropped as early as 20 minutes after resection of the tumor and became undetectable for a few days postoperatively. Then it came back almost normal after 2 weeks. Medial cubital vein was used to take the blood samples. (b) The exponential curve of FGF23 levels indicates that the behavior of FGF23 fits single phase exponential decay model well. The half-life of FGF23 is calculated to be 18.4 minutes. (c) FGF23 levels before as well as 20 and 60 minutes after resection are plotted to a logarithmic graph. Using the semilog transformation formula as shown, the half-life of FGF23 is calculated to be 18.9 minutes. 
Table 1 Literature review

\begin{tabular}{|c|c|c|c|c|c|c|c|c|}
\hline Case & Authors \& year & Age & Sex & Tumor location & $\begin{array}{c}\text { Size } \\
(\mathrm{mm})\end{array}$ & Diagnosis & Immunohistochemistry & Symptom \\
\hline 1 & $\begin{array}{l}\text { David et al., } \\
1996\end{array}$ & 60 & $\mathrm{~F}$ & Frontal base & N/A & РMTMCT & $\begin{array}{l}\text { vimentin+ cytokeratin- } \\
\text { EMA- S100- chromoganin } \\
\text { A- desmin- factorVIII } \\
\text { Ham56 }\end{array}$ & Hip pain \\
\hline 2 & $\begin{array}{l}\text { Gonzalez-Compta et al., } \\
1998\end{array}$ & 69 & $\mathrm{~F}$ & $\begin{array}{l}\text { Ethmoid sinus, } \\
\text { anterior fossa }\end{array}$ & N/A & РMTMCT & N/A & $\begin{array}{l}\text { Bone pain, } \\
\text { walking difficulty }\end{array}$ \\
\hline 3 & $\begin{array}{l}\text { Sandhu et al., } \\
2000\end{array}$ & 46 & M & $\begin{array}{l}\text { Cribriform } \\
\text { plate, } \\
\text { ethmoid sinus }\end{array}$ & N/A & Hemangiopericytoma & $\begin{array}{l}\text { SMA+ vimentin+ NSE+ } \\
\text { keratin- CD34- EMA- } \\
\text { GFAP- S100- Leu7- } \\
\text { chromoganin- desmin- }\end{array}$ & Multiple fractures \\
\hline 4 & $\begin{array}{l}\text { Reis-Filho et al., } \\
2004\end{array}$ & 47 & $\mathrm{~F}$ & $\begin{array}{l}\text { Cavernous } \\
\text { sinus }\end{array}$ & 30 & PMTMCT & $\begin{array}{l}\text { CD34- EMA- MSA+ } \\
\text { desmin- S100- CD68- }\end{array}$ & $\begin{array}{l}\text { Muscle pain and } \\
\text { weakness, } \\
\text { visual disturbance }\end{array}$ \\
\hline 5 & $\begin{array}{l}\text { Yoshioka et al., } \\
2006\end{array}$ & 45 & M & Clivus & N/A & PMTMCT & N/A & $\begin{array}{l}\text { Neck pain, XII } \\
\text { palsy }\end{array}$ \\
\hline 6 & $\begin{array}{l}\text { Kaylie et al., } \\
2006\end{array}$ & 46 & $\mathrm{~F}$ & $\begin{array}{l}\text { Jugular } \\
\text { foramen }\end{array}$ & N/A & РMTMCT & N/A & $\begin{array}{l}\text { Tinnitus, vertigo, } \\
\text { multiple fractures, } \\
\text { bone pain }\end{array}$ \\
\hline 7 & $\begin{array}{l}\text { Uno et al., } \\
2011\end{array}$ & 61 & M & $\begin{array}{l}\text { Cribriform } \\
\text { plate }\end{array}$ & 22 & PMTMCT & $\begin{array}{l}\text { FGF23+ CD34- EMA- } \\
\text { PR- }\end{array}$ & Pain in entire body \\
\hline 8 & $\begin{array}{l}\text { Uno et al., } \\
2011\end{array}$ & 53 & $\mathrm{~F}$ & Temporal bone & 20 & PMTMCT & $\begin{array}{l}\text { FGF23+ CD34- EMA- } \\
\text { PR- }\end{array}$ & Pain in entire body \\
\hline 9 & $\begin{array}{l}\text { Andreopoulou et al., } \\
2011\end{array}$ & 63 & $\mathrm{~F}$ & $\begin{array}{l}\text { Cribriform } \\
\text { plate }\end{array}$ & N/A & No surgery & N/A & N/A \\
\hline 10 & $\begin{array}{l}\text { Kobayashi et al., } \\
2011\end{array}$ & 53 & $\mathrm{~F}$ & Temporal bone & N/A & PMTMCT & FGF23+ & $\begin{array}{l}\text { Bone pain, } \\
\text { muscle weakness }\end{array}$ \\
\hline 11 & $\begin{array}{l}\text { Battoo et al., } \\
2012\end{array}$ & 34 & $\mathrm{~F}$ & $\begin{array}{l}\text { Cribriform } \\
\text { plate, } \\
\text { ethmoid sinus, } \\
\text { nasal cavity }\end{array}$ & N/A & Giant cell tumor & $\begin{array}{l}\text { vimentin+ S100- } \\
\text { EMA- synaptophysin- } \\
\text { chromogranin- leukocyte } \\
\text { common antigen- }\end{array}$ & $\begin{array}{l}\text { Muscle weakness, } \\
\text { epistaxis, nasal } \\
\text { blockage }\end{array}$ \\
\hline 12 & $\begin{array}{l}\text { Bower et al., } \\
2012\end{array}$ & 67 & $\mathrm{~F}$ & $\begin{array}{l}\text { Cribriform } \\
\text { plate, } \\
\text { frontal base }\end{array}$ & 74 & PMTMCT & $\begin{array}{l}\text { FGF23+ vimentin+ S100- } \\
\text { EMA- GFAP- CD34- } \\
\text { SMA- CAM 5.2- desmin- } \\
\text { CD31-MIB- 1low }\end{array}$ & $\begin{array}{l}\text { Depression, } \\
\text { urinary and fecal } \\
\text { incontinence, } \\
\text { apathy, abulia }\end{array}$ \\
\hline 13 & $\begin{array}{l}\text { Chokyu et al., } \\
2012\end{array}$ & 57 & M & Sphenoid ridge & 27 & PMTMCT & N/A & Multiple fractures \\
\hline 14 & $\begin{array}{l}\text { Tarasova et al., } \\
2013\end{array}$ & 67 & $\mathrm{~F}$ & Lt frontal base & 17 & No surgery & N/A & $\begin{array}{l}\text { Pain in entire body, } \\
\text { multiple fractures, } \\
\text { muscle weakness }\end{array}$ \\
\hline 15 & $\begin{array}{l}\text { Mathis et al., } \\
2013\end{array}$ & 28 & $\mathrm{~F}$ & $\begin{array}{l}\text { Cribriform } \\
\text { plate }\end{array}$ & 18 & PMTMCT & $\begin{array}{l}\text { FGF23+ SMA+ CD34- } \\
\text { EMA- S100- }\end{array}$ & $\begin{array}{l}\text { Back stiffness, } \\
\text { muscle weakness }\end{array}$ \\
\hline 16 & $\begin{array}{l}\text { Mathis et al., } \\
2014\end{array}$ & 32 & M & $\begin{array}{l}\text { Cribriform } \\
\text { plate, } \\
\text { ethmoid sinus, } \\
\text { nasal cavity }\end{array}$ & N/A & РMTMCT & $\begin{array}{l}\text { FGF23+ SMA+ } \\
\text { vimentin+ CD34- EMA- } \\
\text { GFAP- synap.- calponin- } \\
\text { collagenIV- keratin- }\end{array}$ & $\begin{array}{l}\text { Hip and low back } \\
\text { pain }\end{array}$ \\
\hline 17 & $\begin{array}{l}\text { Gulwani et al., } \\
2014\end{array}$ & 40 & $\mathrm{~F}$ & Clivus & N/A & $\begin{array}{l}\text { Lipomatous } \\
\text { hemangiopericytoma }\end{array}$ & $\begin{array}{l}\text { vimentin+ CD34+ EMA- } \\
\text { GFAP- factorVIII- }\end{array}$ & $\begin{array}{l}\text { Headache, alerted } \\
\text { sensorium }\end{array}$ \\
\hline $\begin{array}{l}18 \\
\text { (Current } \\
\text { case) }\end{array}$ & Current study & 38 & $\mathrm{~F}$ & $\begin{array}{l}\text { Cribriform } \\
\text { plate }\end{array}$ & 10 & PMTMCT & $\begin{array}{l}\text { FGF23+ CD34- EMA- } \\
\text { S100- }\end{array}$ & $\begin{array}{l}\text { Pain in entire body, } \\
\text { muscle weakness }\end{array}$ \\
\hline
\end{tabular}

Abbreviations: PMT, phosphaturic mesenchymal tumor, mixed connective tissue variant; N/A, not available. 
calculated the half-life of FGF23 as 21.5 minutes using semilog transformation equation [22], which fits well with our result. Khosravi et al. used a single phase exponential decay model and calculated the half-life as 46-58 minutes [21]. They claimed that their methods fit better than semilog transformation equation used by Takeuchi et al. The large difference in the values between the above two studies may simply reflect the different methods used for calculation and/or individual variation in FGF23 clearance [21]. In this study, the above two mathematical models resulted in the very similar values, which were also consistent with the study by Takeuchi et al., and therefore we determined the half-life as approximately 18.5 minutes. Serum iron level and renal function are reported to effect the synthesis, degradation and clearance of serum FGF23 [23]. These factors may have led to the difference of calculation result between the current study and the previous reports [21, 22]; however, the lack of detailed data in the previous reports precludes further analysis. The short half-life of FGF23 may potentially allow intraoperative rapid assessment of the residual tumor once a reliable testing with a short turn-around time [24] becomes widely available in the future.

In conclusion, we analyzed the half-life of FGF23 as approximately 18.5 minutes based on the serial measurements of serum FGF23 level in a case of TIO caused by intracranial PMTMCT. This short half-life and the dramatic decline in FGF23 level noted shortly after tumor removal may indicate that intraoperative assessment of FGF23 level would help us predict the extent of resection and the possible cure of this endocrinologically active tumor.

\section{Acknowledgement}

The contributions of the authors were as follows. T.H. and S.T. designed and performed the research, contributed to the data analysis and wrote the manuscript. T.H., S.T., H.N. and M.S. performed surgery and endovascular procedure and reviewed the data. S.F. analyzed the detailed data of serum FGF23. M.I. examined the pathological findings and diagnosed. S.F., M.I. and N.S. contributed to discussion, reviewed and edited the manuscript. Furthermore, T.H. sincerely thanks Drs. Ryoko Niwa and Sachiko Endo for their support.

\section{Disclosure}

All authors have no conflict of interest.

\section{References}

1. Folpe AL, Fanburg-Smith JC, Billings SD, Bisceglia M, Bertoni F, et al. (2004) Most osteomalacia-associated mesenchymal tumors are a single histopathologic entity: an analysis of 32 cases and a comprehensive review of the literature. Am J Surg Pathol 28: 1-30.

2. Hori M, Shimizu Y, Fukumoto S (2011) Minireview: fibroblast growth factor 23 in phosphate homeostasis and bone metabolism. Endocrinology 152: 4-10.

3. Shimada T, Mizutani S, Muto T, Yoneya T, Hino R, et al. (2001) Cloning and characterization of FGF23 as a causative factor of tumor-induced osteomalacia. Proc Natl Acad Sci U S A 98: 6500-6505.

4. Endo I, Fukumoto S, Ozono K, Namba N, Inoue D, et al. (2015) Nationwide survey of fibroblast growth factor 23 (FGF23)-related hypophosphatemic diseases in Japan: prevalence, biochemical data and treatment. Endocr J 62: 811-816.

5. Yamazaki Y, Okazaki R, Shibata M, Hasegawa Y, Satoh $\mathrm{K}$, et al. (2002) Increased circulatory level of biologically active full-length FGF-23 in patients with hypophosphatemic rickets/osteomalacia. J Clin Endocrinol Metab 87: 4957-4960.
6. Yoshioka K, Nagata R, Ueda M, Yamaguchi T, Konishi Y, et al. (2006) Phosphaturic mesenchymal tumor with symptoms related to osteomalacia that appeared one year after tumorectomy. Intern Med 45: 1157-1160.

7. Uno T, Kawai K, Kunii N, Fukumoto S, Shibahara J, et al. (2011) Osteomalacia caused by skull base tumors: report of 2 cases. Neurosurgery 69: E239-244.

8. Tarasova VD, Trepp-Carrasco AG, Thompson R, Recker RR, Chong WH, et al. (2013) Successful treatment of tumor-induced osteomalacia due to an intracranial tumor by fractionated stereotactic radiotherapy. $J$ Clin Endocrinol Metab 98: 4267-4272.

9. Mathis DA, Stehel EJ Jr, Beshay JE, Mickey BE, Folpe AL, et al. (2013) Intracranial phosphaturic mesenchymal tumors: report of 2 cases. J Neurosurg 118: 903-907.

10. Gulwani H, Garg N (2014) A 40-year-old woman with intracranial bleed and osteomalacia. Brain Pathol 24: 419-420.

11. Bower RS, Daugherty WP, Giannini C, Parney IF (2012) Intracranial phosphaturic mesenchymal tumor, mixed connective tissue variant presenting without oncogenic osteomalacia. Surg Neurol Int 3: 151. 
12. David K, Revesz T, Kratimenos G, Krausz T, Crockard HA (1996) Oncogenic osteomalacia associated with a meningeal phosphaturic mesenchymal tumor. Case report. J Neurosurg 84: 288-292.

13. Chokyu I, Ishibashi K, Goto T, Ohata K (2012) Oncogenic osteomalacia associated with mesenchymal tumor in the middle cranial fossa: a case report. $J$ Med Case Rep 6: 181.

14. Battoo AJ, Salih S, Unnikrishnan AG, Jojo A, Bahadur $\mathrm{S}$, et al. (2012) Oncogenic osteomalacia from nasal cavity giant cell tumor. Head Neck 34: 454-457.

15. Kobayashi K, Nakao K, Kawai K, Ito K, Hukumoto S, et al. (2011) Tumor-induced osteomalacia originating from the temporal bone: a case report. Head Neck 33: 1072-1075.

16. Kaylie DM, Jackson CG, Gardner EK (2006) Oncogenic osteomalacia caused by phosphaturic mesenchymal tumor of the temporal bone. Otolaryngol Head Neck Surg 135: 653-654.

17. Gonzalez-Compta X, Mañós-Pujol M, Foglia-Fernandez M, Peral E, Condom E, et al. (1998) Oncogenic osteomalacia: case report and review of head and neck associated tumours. J Laryngol Otol 112: 389-392.

18. Reis-Filho JS, Paiva ME, Lopes JM (2004) August 2003: 47-year-old female with a 7-year history of osteomalacia and hypophosphatemia. Brain Pathol 14: 111-112, 115.

19. Sandhu FA, Martuza RL (2000) Craniofacial hemangiopericytoma associated with oncogenic osteomalacia: case report. J Neurooncol 46: 241-247.

20. Andreopoulou P, Dumitrescu CE, Kelly MH, Brillante BA, Cutler Peck CM, et al. (2011) Selective venous catheterization for the localization of phosphaturic mesenchymal tumors. J Bone Miner Res 26: 1295-1302.

21. Khosravi A, Cutler CM, Kelly MH, Chang R, Royal RE, et al. (2007) Determination of the elimination halflife of fibroblast growth factor-23. J Clin Endocrinol Metab 92: 2374-2377.

22. Takeuchi Y, Suzuki H, Ogura S, Imai R, Yamazaki Y, et al. (2004) Venous sampling for fibroblast growth factor-23 confirms preoperative diagnosis of tumorinduced osteomalacia. J Clin Endocrinol Metab 89: 3979-3982.

23. Lewerin C, Ljunggren Ö, Nilsson-Ehle H, Karlsson MK, Herlitz H, et al. (2017) Low serum iron is associated with high serum intact FGF23 in elderly men: The Swedish MrOS study. Bone 98: 1-8.

24. Shimizu Y, Fukumoto S, Fujita T (2012) Evaluation of a new automated chemiluminescence immunoassay for FGF23. J Bone Miner Metab 30: 217-221. 